\title{
Woman and Management: A Conceptual Review, with a Focus on Muslim Women in Management Roles in Western and in Muslim-Majority Countries
}

\author{
Christopher Adam Bagley¹, Mahmoud Abubaker², Afroze Shanaz ${ }^{3}$ \\ ${ }^{1}$ Faculty of Social, Human and Mathematical Sciences, University of Southampton, Southampton, UK \\ ${ }^{2}$ Leeds Business School, Leeds Beckett University, Leeds, UK \\ ${ }^{3}$ Independent Researcher, Liverpool, UK \\ Email: chrisbagley2@gmail.com, M.Abubaker@leedsbeckett.ac.uk, Shahnazfroze@yahoo.se
}

How to cite this paper: Bagley, C.A., Abubaker, M. and Shanaz, A. (2018) Woman and Management: A Conceptual Review, with a Focus on Muslim Women in Management Roles in Western and in Muslim-Majority Countries. Open Journal of Business and Management, 6, 498-517. https://doi.org/10.4236/ojbm.2018.62038

Received: April 2, 2018

Accepted: April 27, 2018

Published: April 30, 2018

Copyright (c) 2018 by authors and Scientific Research Publishing Inc. This work is licensed under the Creative Commons Attribution International License (CC BY 4.0).

http://creativecommons.org/licenses/by/4.0/

\begin{abstract}
We consider the roles of Muslim women managers, executives and professionals in three ways: as women qua women; as women of the Muslim diaspora in Western countries; and as women in Muslim Majority Cultures (MMCs). In reviewing the literature on the "glass ceiling" which prevents women achieving parity with men in middle and senior management roles, we are impressed by the work of Helgeson and Johnson on the special qualities of women in management roles, and compare their social psychological model with accounts of "strong" Muslim women who, drawing on Islamic traditions have performed many leadership roles outside of the traditional family. Nevertheless, it is Muslim women's strength as strong family managers, with men being supporters rather than leaders of such family roles, which we generalise in describing an ideal model of a Muslim women manager. We draw too on traditional Islamic models in describing the kind of capitalist enterprise which may thrive in MMCs, and in which women will play leading roles. Nevertheless, we observe that in many MMCs non-Muslim (but strong) traditions of patriarchy often prevail, and subvert women's search for higher education and leadership roles. This review advocates reforms in MMCs which will allow women to enter the world of employment, and to rise to higher managerial positions. At the same time, we observe the strong prejudices against Muslim women entering managerial positions in Western cultures, based on multiple, intersecting prejudice and discrimination against women; against visible ethnic minorities; and against those who are visibly Muslim. Further qualitative work in this field is advocated.
\end{abstract}




\section{Keywords}

Female Managers, Muslim Women, Muslim Cultures, Discrimination, Patriarchy, Intersectionality, Islamophobia, Patriarchy

\section{Introduction}

The authors of this paper have two major concerns. The first is the discrimination against Muslim women by employers in Western nations (those countries in whom the majority of the population are of European heritage). Our second concern, as Muslims, is the discrimination against women as managers and as professionals, in Muslim Majority Cultures (MMCs) - the Muslim cultures of North Africa, the Middle East, and Southern Asia. We cannot address these two concerns without first considering the range of factors which can impede women (of whatever ethnicity or religion) from reaching management roles at a variety of levels, in the companies in Western nations which choose to employ them. We shall argue that the identified strengths of women managers in Western countries may also apply, in a culturally modified way, to Muslim women seeking occupational advancement in MMCs.

The first tier of literature which we consider concerns the barriers to the employment of women (regardless of ethnicity and religion) in management in American and European cultures. The second tier of literature concerns the issues of intersectionality, in which Muslim women seek professional, management and executive roles in the external workforce in Europe and America, following "the Muslim diaspora" (Syed \& Pio, 2016) [1]. The third set of literature is concerned with the progress of women in management and professional roles in Muslim-majority countries. We want to see if there can be a coherent model of research which covers these three tiers or domains of literature, as a prelude to proposing both quantitative and qualitative studies on problems encountered by Muslim women in a particular types of business organisation in Muslim Majority Cultures.

\section{Women in Management: "Western" Studies}

The barriers to women's progress in taking management roles in Muslim countries such as Palestine, Jordan and Bangladesh may first of all, be similar in a number of ways to the issues facing women in Western countries, and especially minority women who seek to attain status in managerial roles (Rizzo, Abdel-Latif \& Maeyer, 2007) [2]. The study of women in management roles, and the barriers to such attainment in Western countries has recent genesis (Alvesson \& Billing, 1999) [3]. It remains clear that in all countries of the world there remains a "glass ceiling" (of variable height and thickness) which prevents women attaining the highest ranks in business organisations-when they do succeed, it is often in specialised roles such as human relations management, or 
in specialised technical areas which do not require male-type aggression (Paludi, 2013) [4].

An ILO (2015) study [5], updating World Bank (2012) [6] profiles of women in management, surveyed 108 countries and reported significant advances in the proportions of women in middle and senior management roles. While women outnumbered men in the areas of human relations, publicity and communications, they were underrepresented in fields such as sales, marketing and higher management. The ILO study identified many different ways in which women said that they could advance their careers, including peer support and mentoring, and the pressure for adequate Work Life Balance (WLB) benefits. Certain nations had not made progress in women's role advancement however, and the eleven nations ranked lowest by ILO were all Muslim-majority cultures, many of them bracketed as "low to middle income" countries. Only Turkey and Palestine ranked with "developed" nations in the proportions of women in the more senior managerial roles.

In 2016 women occupied 24 percent of senior roles in the North American Fortune 500 companies, an increase of 3 percent since 2011. But in 2016, in 33 percent of global companies there were no women in senior management. The authors of the report reaching these conclusions commented: "The percentage of women in senior roles is slowly growing worldwide, but at this pace we won't reach parity for decades." (Catalyst, 2017) [7]. In a British analysis Francke (2014) [8] pointed to "the power of role models"- the prominence and activism of powerful women in British institutions and companies who are exemplars of how success may be achieved. In fact, this report shows that knowledge of discrimination, potential or actual, can make women grudgingly accept rather low levels of achievement in organisations.

Carter \& Silva (2010) [9] observing that only three percent of Fortune 500 companies were headed by a female CEO, report on a follow-up study of cohorts of male and female MBA graduates in America, and showed that after graduating women were significantly more likely to be appointed to positions of lower rank and salary than their male counterparts. But an early appointment to a lower ranked or rewarded managerial post tended to determine a woman's whole career pattern - a similar finding to that of Metcalfe (2010) [10] in her research on a number of Muslim-majority cultures. Women who did not take "child-care breaks" remained disadvantaged in American organisations. In this analysis, all too often women managers were seen as "taking care", while male managers were viewed (by the senior males who hired them) as "taking charge", and were the likely candidates for further promotion. However, we argue below for a Muslim-model in which the "caring" role of being a strong family manager can translate into a senior management role in an enterprise which in a sense, remains a family, fulfilling both ethical and financial goals.

The positive aspect of women's role as senior managers comes from the influential work of Americans Sally Helgeson and Julia Johnson [11] [12]. The first 
edition of their insightful and ground-breaking book The Female Vision: Women's Real Power at Work appeared in 1990, and a largely rewritten version of this book, taking account of the financial decline of 2008, was published in 2010. Their accounts of the successful female manager which have emerged from this research have been broadly acclaimed, and their model is persuasive. In their original research they conducted extensive interviews with 80 successful women managers, and "tracked" the daily routines of a number of the managers. They argue that women's management style may have a sociobiological basis: women perceive differently, relate differently, and control differently when compared with their male counterparts (Helgeson, 2018) [12].

In the model which emerged from this research, women managers "take in" more detail in arriving at decisions-they are more analytical, rational and thoughtful. They act and organise differently from men, in ways which reflect a superior "emotional intelligence" compared with males. They are more attentive to the emotional needs of those below them, and above them. These are skills which the alpha-male manager often lacks. When the organisation is under threat, the male leader may enter a "fight or flight" mode, while the woman leader may "circle the wagons", using her male counterparts with strategic intelligence. Women managers support depressed and troubled employees, rather than firing them. In Helgesson's (2017) [12] account, they get the best out of people. Their approach to management is qualitative, rather than quantitative. Any male bean-counter can calculate the bottom line: it takes a person who combines emotional and strategic intelligence to know how the organisation should change in order to improve the bottom line. This is one of the (several) ways in which women may excel in management. Woman are more empathic, less interested in profit for its own sake, more interested in the firm as a socially responsible organisation-although, as Belinda Parmar (2014) [13] argues, empathy may be the royal road towards profitability.

In this feminist model, women may lack (or ignore) any innate drive to "control and subjugate": their major driver, rather, is to meet the emotional needs of employees and customers alike, through co-operation and understanding in seeking to maximise a company's potential. Empathy with potential customers and clients is another important way in which women often outmatch men. Intelligent women executives do not engage in needless battles, and they may exercise the option to walk away (e.g. resign) from situations in which an unintelligent alpha male manager spoils for a fight. This may be one reason why there is a dearth of women in the top ranks of management (Parmar, 2014; Gordon, 2016) [13] [14].

An important question is this: if women, as a group, possess such excellent management skills, why are they underrepresented, and discriminated against, in so many Western enterprises (Bullough, Moore \& Kalafotoglu, 2017) [15]? One answer seems to be that not only are many men aggressively hanging on to positions of power in ways which are dysfunctional for their organisations: they 
operate, cognitively, within a realm of cognitive dissonance, their innate prejudices unshaken by contrary evidence.

In reading these accounts of successful women managers, we are struck by the similarity of this model with the accounts of the successful woman in Muslim cultures, past and present, who is not only supremely successful as a "strong family manager", but also in modern times when she graduates from university and enters professional employment is successful because she is a successful wife and mother, effectively running two organisations according to the same principles based on "emotional intelligence" [16].

We should add that this account of women managers' potential for success is based on an idealised model, and there are a number of ways in which men can undermine the "emotional friendliness" of women in organising work settings and commercial enterprises. Men can disrupt women's organisational power through "the masculine managerialism of conquest, competition and control" (Kerfoot \& Knights, 1994; Knights, 2017) [17] [18]. Male sexism moves non-formally into many situations in the workplace, into sexually demeaning and even sexually assaultive comments, strategies and behaviours imposed on those women below them, or who are perceived as threats to their hegemony (Bates, 2014) [19].

In profound contrast, the Islamic solution to the mixing of genders within social institutions is to emphasise the ethical ground of respect and modesty, in a system of gender plurality. Contrary to Knights' (2015) [20] thesis that "if bodies are to matter, binaries need to shatter", Islam asserts the divinely inspired plurality of male and female sexuality, linked together by the ethics of modesty and mutual service. Women in organisations in which a majority of employees are Muslim will not, we assert, encounter sexual harassment. Such behaviour is anathema within a culture which is extremely cautious about sexual expression outside of the family unit. In organisations, women are not treated in the same way that men are treated: rather they are perceived as profoundly different, having special needs (for respect and modesty), with personal rights in their child-care roles not afforded to men. Muslim organisations are most likely to discriminate in failing to hire women for managerial or professional positions on grounds of patriarchy; but once women have been hired, although their promotion may be slow, their treatment will not involve sexual harassment of the kind recorded by Laura Bates (2014) [19] in Western cultures.

\section{Minority and Muslim Women Seeking Managerial and Professional Employment in "Western" Organisations}

Women (and especially minority women) who seek to rise in business organisations face the problems of "intersectionality", in which several disadvantaged statuses (e.g. gender, ethnicity, migration status) coincide (Phoenix, 2006; Shen et al., 2009) [21] [22]. Minority women may be forced to adopt roles of conformity and compliance, acknowledging and supporting the ambitions of male 
managers if they are themselves to seek advancement (Purdie-Vaughns \& Eibach, 2008; Ng \& Sears, 2010) [23] [24]. Women in such settings may have to adopt "fluid identities" in order to be successful, knowing how to "present themselves in everyday life" (Goffman, 1978) [25] in roles in which they seek to avoid imposed stereotypes (Afshar, 2012; Veenstra, 2012) [26] [27]. In these accounts the very flexibility of a women's identity in a male-dominated world of industry and commerce allows these women to find niches and avenues of power (Afshar, 2012) [26]. It may be, as Parmar (2014) [13] argues, that women's development of the capacity for warmth and empathy allows them to understand the nuances of managerial roles in organisations which men control, in ways which allow them to both successfully serve and to manage important organisational roles.

Professional developments in HRM practice have, too often, reflected public stereotypes of ethnic minority women (Shen et al., 2009) [22]. In response to such prejudice and misunderstanding, self-help groups have developed for mentoring Muslim women seeking advancement in management roles (Grine, 2014) [28]; in addition, explicitly multicultural policies in countries such as Canada (Mahadevan \& Mayer, 2017) [29] may be helping the rise of Muslim women in management roles. But even "progressive" HR managers in North America have tended to tend to focus on gender rather than on ethnicity or religion when promoting policies for employment equity (Kameneau \& Fearful, 2006) [30]. Indeed, Muslim women seeking occupational advancement in non-Muslim societies in Europe and North America face the additional challenge of ethnic and religious prejudice, which when combined with sexist values, can be major obstacles to obtaining professional employment, or executive roles in commercial organisations (Kumra \& Manfredi, 2012; Bagley \& Abubaker, 2017 [31] [32]. In England a Muslim woman has to apply for twice as many vacancies as her "white" English sister, before she is even offered an interview for a professional post; the same pattern of discrimination occurs in The Netherlands (Abubaker \& Bagley, 2017) [33].

Ali et al. (2017) [34] place such discrimination within a three-tier framework, in which workplace discrimination (including the failure to provide adequate WLB support) combines within macro, meso and micro-level factors with complex "relational intersections" which act to exclude Muslim women in Western countries from having access to the external labour market at a level which matches their education, and their aspirations. We have adopted this heuristically useful three-tier model of Ali et al. (2016) [35] in framing the present review of literature.

In all Western countries, women of "the Muslim diaspora" face particular challenges, since the wearing of the hijab (head covering) and modesty of dress marks a woman for discrimination and abuse both in public places, and in employment situations (Syed et al., 2005; Ali et al., 2017) [34] [36]. Muslim women face greater amounts of employment discrimination than do Muslim men (Bag- 
ley \& Abubaker, 2017) [32]. This is a major challenge for research on human relations practice (Ali et al., 2017) [34], and has led the researchers working under Syed's leadership [37] [38] [39] [40] on prejudice, discrimination and the impact on women labour force in 18 different countries, to seek, largely in vain for common threads in gender and diversity polities in a variety of cultures in which Muslims form varying proportions of the population.

Syed and Colleagues (2008 to 2016) [37] [38] [39] [40] argue that HRM policy in societies marked by ethnic and religious diversity must adopt complex, individualised models of practice reflecting a country's particular history and social structure with regard to the treatment and power relations of majority and minority groups. This approach, though manifestly sensible is difficult to adopt systematically in practice, and we have yet to see an example of how it has been successfully applied as a comprehensive, explanatory framework. The question, as Rodriguez et al. (2016) [41] posed with regard to gender, ethnicity and "intersectionality" is: "Where do we go from here?" Eden \& Gupta (2017) [42] do offer valuable data analysis in exploring why women are underrepresented in management roles in countries at various stages of development. In this analysis, economic growth is by means a guarantee of increased gender equality in management.

That questions about increasing the role of "minority women" in organisations must be asked, is clear from the work of Mahadevan and her colleagues (Mahadevan et al. 2017) [43] [44]. They attempt to develop relevant models through European and international descriptions of HRM practice (focusing in particular on Muslims of both genders who are part of the "Muslim diaspora" in Germany and elsewhere in mainland Europe). Their emerging model is one of "reflexive HRM practice" (Mahadevan, et al. 2017) [29] [44]. This is a bold model, since it requires HRM managers to engage in reflexive dialogue in how they perceive and understand the aspirations of upwardly-mobile Muslims.

Translated into the critical realist model (Bagley et al., 2016) [45] this implies that the phenomenon of absence, of ignoring Muslim aspirations, is being replaced in a reflexive dialogue as a prelude to morphogenesis, the foundation of structural and value change. Britain has certainly not yet gone much beyond the stage of denial (the state of absence), that of ignoring the reality of Muslim women's occupational presence and their aspirations, in anything other than stereotyped terms (Abubaker \& Bagley, 2017; Bagley \& Abubaker, 2017) [32] [33]. Muslim women in management roles in countries such as Britain are a small fraction of all women in management (Tariq \& Syed, 2017) [46]. In order to succeed they have to draw on intersecting support networks, and to engage in pioneering education on behalf of Muslim women in leadership roles.

\section{Women's Role in Traditional Islamic, Muslim-Majority Cultures}

Traditionally, women have held both powerful and protected roles in Muslim 
societies. Their duality of role-supporting and leading their family, and exercising wider social power-is not usually understood by non-Muslims. Muslim women's equality has been proportional rather than absolute, and specific portions of The Qur'an specify that women require special treatment and respect in roles concerning family relationships, marriage and inheritance (Mernissi, 1991) [47]. Nevertheless, the Qur'an clearly prescribes the absolute moral, structural and spiritual equality of men and women in many roles and social institutions (Wadud, 1999; Esposito, 2003) [48] [49].

Women in Islam have played important roles as leaders of commerce (following the example of Kadijah, the first Muslim woman); as religious scholars (Aish'ah, Umm Salama, and many others); as governors and administrators; and as military leaders (Ghandanfar, 2001) [50]. The "golden age" of the Caliphates until 1258 (Esposito, 1998) [51], and the many prominent women in Islam are often forgotten, and today a sub-Islamic patriarchy in nominally Muslim countries often prevails, in ways which oppress women (Hashmi, 2000; Bagley et al., 2017; Shahnaz et al., 2013) [52] [53] [54]. This is despite the abundant evidence from Qur'an and Sunnah (the teaching, and the lived example of Prophet $\mathrm{Mu}$ hammad) that women have in virtually every domain, equal rights with men (Mernissi, 2001; Roald, 2001; Al-Khayyat, 2007) [55] [56] [57].

Anwar (2006) [58] too draws on Qur'anic and Sunnah sources in developing a philosophical argument about "the ontology of selfhood" for Muslim women. She develops a pluralistic model-women, from the time of Adam's wife, have profound differences from men, but they also have the rights of equality of selfhood in terms of sexual identity and aspirations. In this model, women are not subordinated to men in Islamic cultures. Modern Islamic feminists draw on the traditional writings of Islam in showing that this theology asserts the net equality of woman (Lovat, 2012) [59].

In the Arab world, according to the Moroccan sociologist Fatima Mernissi (2001) [55], male hegemony leads to distorted and biased interpretations of Qur'an and Sunnah (the life and teaching of Prophet Muhammad). For Mernissi the essential first step is for all women to achieve at least full secondary education, and to equal men in the number of university graduates. These arguments parallel the equally strong account of women's equality in Islam advanced by Anne-Sophie Roald, from her analysis of Qur'anic and Hadith sources (Roald, 2001) [56]. In many Muslim-majority societies today women are making considerable strides in educational equality, the first step in attaining the gender equality which Islam ordains (Ahmed, 1992) [60]. And as Ramadan (2010) [61] urges, women achieving structural and value equality with men in Islam, have the right to choose their own route along "the straight path of Islam", not that which men (including some "liberal" scholars) think that they should follow. For example, the wearing of the hijab is a proud (and also voluntary) statement of the identity of a Muslim woman, and not a subordinated form of obligated religious attire. 
There are now eloquent voices in modern-day Islamic feminism which argue the case for women's role in the worlds of education, the professions, commerce and industry. Foremost amongst these is the Egyptian scholar Heba Raouf Ezzat $(2007,2008)$ [62] [63]. She argues that Muslim women who seek equality are seeking a dignity which links with a worldwide movement for women's equality, regardless of their religious identity: "Through networks of mobilization, fair trade campaigns, alternative media and grassroots projects woman can create spaces where sustainable development comes close to realisation." (2007, p. 190) [63]. For Arab countries she advocates the feminist reform of authoritarian regimes. Furthermore: “Unless women's struggle for dignity is rooted in Islam, we risk losing our compass." (Ezzat, 2008, p. 109) [63]. On Muslim women in business organisations Ezzat develops the model of zakat, the Islamic principle of gift-giving and engaging in economic activity in order to contribute to fellow citizens for welfare purposes, within a commercial framework which avoids exploitation through usury and the charging of interest. Thus Islamic capitalism is (or should be) fundamentally welfare- rather than profit-oriented. In this model women may be managers of an industrial, welfare enterprise which is like a family, large or small: and men may be the worker bees whose industry makes the system work. These ideas are elaborated by Murphy \& Smolarski (2018) [16].

Ahmad (2004) [64] also observes that: "Islamic economics represents an effort to search for a new participation ... The idea is to address basic economic problems from a moral and socially responsible perspective. We seek to reintegrate economics with ethics... our approach is more holistic, and all embracing ... While abolition of interest and introduction of zakat are two pillars of the Islamic economic system, Islamic economics represents much more than that... Productive efficiency and distributive justice are twin objectives, inalienable elements of an integrated whole." (p. 39)

There is an interesting parallel between this model of women managers in Arab countries who transfer their skills as "strong family managers" into the management of public and commercial enterprises-bringing with them, intuitively, the model of the empathic, perceptive and psychologically strong women professionals-and the model of women managers and executives identified in Western cultures by Parmar (2014) [13], and Helgeson (2018) [12]. Islam in this ideal model simply draws out the best of women's "natural" managerial skills (Anwar, 2006) [58]. However, it is clear from the accounts of Middle Eastern human relations policy that a just and rational model of women's equality in employment is still struggling to emerge (Jamili, Sidani \& Safieddine, 2005; Sidani, 2005; Kalafatoglu \& Mendoza, 2017; Spierings, 2015) [65] [66] [67] [68].

Ezzat's (2007) [63] account of enterprises in Muslim countries being service rather than profit oriented is, we believe, crucially important, since Western entrepreneurs investing in Arab and other Muslim-majority countries risk making the mistake of failing to understand the reluctance of Muslim businesses to employ the sharp-edged, competitive techniques imported from Western capitalism 
[70]. However, the ideal of Muslim-informed enterprises is rarely applied in practice, and business enterprises in Muslim-majority cultures only atypically operate according to Islamic norms (Sidani, 2005; Sultan et al., 2011; Branine \& Pollard, 2010) [66] [69] [70]. An important factor in Muslim majority cultures influencing how businesses organise human relations management may be that non-Muslim, international investors import models of management without any understanding of how Islam requires ethical conduct and relationships between individuals (Branine \& Pollard, 2010; Hutchings et al., 2010) [70] [71]. Another interesting possibility is that women managers serving in patriarchal business systems in Muslim cultures in North Africa and the Middle East, operate with smart intuition in drawing on social capital resources, obtaining for the firm the best kinds of finance, trade deals, and entry in international marketing-successes for which the senior manager, the "elderly patriarch" will take credit (Kalafatoglu \& Mendoza, 2017) [67].

Perceptive analyses of the roles of Muslim women in managerial positions in some Middle Eastern countries comes from the group of scholars led by Beverly Metcalfe (Metcalfe et al. 2006 to 2011; Hutchings et al., 2010; Mellahi et al., 2011) [10] [72]-[78]. Metcalfe observes that:

If one examines Muslim-majority countries governed by Shari 'a, one will find that Islamic interpretation is highly variable and has differential impacts on the role of women (Mernissi, 2001; Roald, 2001; Metcalfe \& Rees, 2010) [56] [57] [78]. ... due to historical events and male domination in Gulf society, there is much confusion between what Islam is, and what is merely culturally associated with Islam. While there is ongoing debate on interpretations of Islamic jurisprudence and women's role... at the root of the barriers to women's progress in the Gulf are traditional masculinist attitudes, which I will call an Islamic Gender Regime... The Islamic gender regime is premised on the biological differences between men and women, and it is these biological differences that determine social function. As such, men and women have complementary but different family responsibilities. Cultural processes assume that a woman will marry early; that her contribution to the family will be as homemaker; that the household will be headed by a man and that the man will provide financially and "protect" the family. Male protection is seen as justification for the exercise of authority over women in all areas of decision making that relates to the public sphere (Metcalfe, 2011, p. 13) [10].

The interpretation of the Muslim authors of the present paper concerning the Islamic perspectives on women as "leaders", is that a man's role as "protector and supporter" of the family means that he is an external person who earns money or who farms for food which he offers to the family manager (who is always a woman). The woman, like Kadijah the first wife of The Prophet, is the manager not only of the household but also of the family business. The subversive patriarchy which tries to assert that men are rulers of women, is un-Islamic (Hashmi, 2000) [52]. A husband acts as the external guard of the household, but 
his role should be complementary to that of his female partner, rather than one of being that of a dominant or controlling person.

Thus women in traditional Islamic societies, are powerful managers of a particular domain, the family. Men are expected to work outside of this family domain to provide financial support, but nevertheless their roles are subordinated to those of women on many issues. Muslim women in some Arabic countries are now exercising power outside of the family, in professional roles, which require management to provide Work Life Balance Benefits which are appropriate for a Muslim culture, and are often different in kind and quality from those offered by Western organisations (Abubaker \& Bagley, 2016) [73]. The "civility" of life in an Islamic organisation is matched by the dignity which a fully developed Muslim culture affords to society at large, including people of all ethnic groups and religions [79].

But in many Muslim-majority countries today male hegemony rather than religious principles derived from Qur'an and Sunnah, governs the conduct of everyday life, including the emancipation, education, employment and promotion of women (Hashmi, 2000; Rizzo, Abdel-Latif \& Meyer, 2007) [2] [52]. How the needs and interests of women in Muslim-majority societies are addressed by human relations management (HRM) policy and practice when they enter the workforce remains unclear in any holistic sense. Indeed, the nature and variations of HRM policies in Muslim-majority cultures have not yet been definitively described, but studies so far undertaken imply that a complex, multi-level model of understanding, integrating cultural, social system and localised variables must be applied (Ali et al., 2016) [35].

Budhwar \& Mellahi (2006) [80] draw together accounts of HRM practices in Iran, Oman, United Arab Emirates, Qatar, Turkey, Egypt, Sudan, Tunisia, Algeria and Morocco, examining the degree to which Islam as a national religion has influenced the values and practices of Human Relations Management in particular countries. They conclude that there is no common pattern, and other factors including recent political and colonial history, localised values, the actual extent to which Islamic values influence social values and social norms, and contrasting cultural aspects all influence how human potential is managed in different enterprises, in contrasted countries. They offer their overview as a "catalyst" for further research, but offer no unifying model of how different Muslim cultures address women's needs and aspirations in the workplace.

Omair (2008 \& 2010) [81] [82] offers a useful review of literature on women in management in Muslim majority cultures (MMCs), as well as a qualitative analysis of women managers' career patterns in the United Arabic Emirates. She argues that most studies of women managers in MMCs have not regarded women as the equivalent of men in pursuing managerial careers: rather, what has been examined has been their motivations in seeking atypical roles. Omair classifies the women in her study into four types: progressive career women, who seek to compete on equal terms with men, in seeking higher managerial roles; 
moderate career women who seek management positions, but not at the highest level, often taking long periods away from paid work for family roles; facilitated career women, who occupy senior managerial and professional roles within family-owned businesses; and idealist career women, occupying senior roles in medical, educational and social service management. This typology has yet to be examined with larger, cross-cultural samples, but may offer a useful model for subsequent research (Panjalingan, 2012) [83]. Saeed, Yousaf \& Alharbi (2017) [84] offer useful findings on women managers in family-led firms: when such firms expand internationally or are awarded state contracts (in India and China), women managers and male directors both gain status and power.

Kemp et al. (2015) [85] offer a statistical analysis of characteristics of 2,805 companies in six Gulf states (KSA, Oman, Qatar, UAR, Bahrain, Kuwait) and partially replicate factors identified in previous research shown to influence proportion of women employed as managers (average, $5.2 \%$ in these six countries). These influences include the survival of patriarchal values; local or biased interpretations of Islam; public sector employment favouring women; women perceived as costly in terms of benefits required; women seen as more likely to be short-term employees; and local political and/or ethnic particularism. Their conclusion that the rapid increase in the numbers of women graduates will lead to more women entering management in these countries, with new pressures and models emerging, is important and should lead to further research.

There is still no clear or unified model of how women are recruited to, and successfully survive in managerial roles in Muslim majority countries (MMCs). We appreciate this lack of clarity about MMCs from our work in Bangladesh, in which (as Muslims) we have, like others, observed the failure of a supposedly Islamic country to address the needs and aspirations of women and children which would fulfil the ideals of Qur'an and Sunnah (Abuznaid, 2006; Bagley et al., 2017; Shanaz et al., 2017) [53] [54] [86].

In Pakistan too, despite ideals concerning the inclusive ethics of a Muslim economic enterprise which gives equal participation to women (Ahmad, 2004) [64], in practice the education of women (and their high rates of illiteracy) compares unfavourably with that of men, and very few Pakistani women achieve professional or managerial status. The scarcity of women in such roles means that no women managers have been studied systematically in Pakistan (Coleman, 2004). [87] In the ILO (2015) [5] survey of women managers in 108 countries, Pakistan ranked last, with only three percent of managers being women, often in junior positions, with little possibility of advancement. Male authoritarianism in Pakistan, contrary to Islamic principles, generally denies the access of qualified women to managerial positions (Morin, Fatima \& Qadir, 2018) [88].

Women have only begun to enter executive and managerial roles in business in Muslim-majority countries in the latter part of the twentieth century, but in increasing numbers-reflecting two factors: the increasing educational attainments of women; and the influence of international organisations who have an 
increasingly prominent role as investors in Islamic countries (Abbas, 2005; Sultan, Weir \& Karake-Shalhoub, 2011) [89] [69]. An emerging pattern is for women of wealthier parents in Muslim-majority societies to attend college, and work successfully after graduating, but then to retire from the world of external work to become the traditionally strong family member, a matriarchal role familiar in Arab culture (Ezzat, 2007) [62]. Increasingly however, Muslim women are choosing to remain in professional and managerial roles, effectively managing two domains, work and family.

Examples of how organisations in two Arab countries accommodate the needs of dual-career women come from studies of how employers in the expanding telecommunications industry (in which women graduates make up about a third of the workforce) regard Work Life Balance benefits in Gaza, Palestine and in Jordan. This qualitative work (Abubaker \& Bagley, 2016 a \& b) [79] [90] showed a range of benefits which do not exist in Western companies. First of all, reflecting the fluidity which exists in Arab countries between worlds of work and family (Nydell, 2012), [91] both men and women employers could receive social visits at work from family and friends: a coffee will be shared for 20 minutes, regardless of work demands. Special deference is given to women allowing them to leave work early in winter months, so that they arrive home safely before dusk. Breast-feeding women (for up to two years after a child's birth) may arrive an hour late and leave work an hour early. Some companies provided onsite day-care, or subsidies for commercial day-care for women employees. Women had a year of maternity leave. Shorter paternity leaves were available for men, but were rarely taken up by men who thought that their roles lay completely outside of the home. However, both men and women would take the month's "honeymoon leave" allowed. In Gaza the companies studied paid for the rebuilding of homes destroyed in the Israeli bombardment, as well as paying the medical expenses and death benefits for employees injured or killed by these bombardments. Both men and women are given special leaves to journey on the Haj (the obligatory once-in-a-lifetime pilgrimage to Makka). The gender-relations ethos was, overall, one of respect for women, and sexual harassment was unthinkable in an Islamic ethos. Within each working day, up to an hour was set aside for ritual washing (wudu) and prayers, which all Muslim employees attended.

Nevertheless, a "glass ceiling" did exist, and only two of the 20 senior managers in the organisations studied were women. Women tended to be promoted diagonally rather than vertically, into specialist roles in human relations, finance and public relations. Companies sought to promote a good public image as generous employers, as one way of marketing products and services. Service rather than profit seemed to be the "bottom line", so long as the company provided enough income stream to adequately reward its employees.

We summarise this overview in a three-level model derived from Ali et al. (2017) and Mahadevan (2017) [34] [44]. This model is outlined in Table 1. 
Table 1. Differential levels of challenge, and outcomes, for women, and for muslim women in management.

\begin{tabular}{|c|c|c|c|}
\hline & All Women & $\begin{array}{l}\text { Muslim Women of the Muslim Diaspora } \\
\text { in Western countries }\end{array}$ & $\begin{array}{l}\text { Muslim Women in Muslim Majority } \\
\text { Cultures }\end{array}$ \\
\hline Macro Level & $\begin{array}{l}\text { Government policies favour \& firms } \\
\text { recognise women's strengths }\end{array}$ & Western countries (e.g. UK) has Equal & $\begin{array}{l}\text { Islam empowers women, extends "family } \\
\text { strength" to "occupational strength" }\end{array}$ \\
\hline Positive Trends & Glass ceiling remains, women not & Opportunity law & Patriarchy may prevail, undermining Islamic \\
\hline Negative Trends & $\begin{array}{l}\text { adequately represented in leading } \\
\text { firms; discrimination still marked }\end{array}$ & Law (e.g. UK) not enforced & $\begin{array}{c}\text { principles, preventing women's entry to } \\
\text { university/employment }\end{array}$ \\
\hline $\begin{array}{c}\text { Meso Level } \\
\text { Positive Trends } \\
\text { Negative Trends }\end{array}$ & $\begin{array}{l}\text { Positive hiring by some firms in } \\
\text { some countries, reflects both } \\
\text { individual and national policies } \\
\text { Discrimination by firms in many } \\
\text { countries, despite national policies }\end{array}$ & $\begin{array}{c}\text { Public sector employers do not } \\
\text { discriminate? } \\
\text { Many private sector firms will not hire } \\
\text { Muslim women: intersectional } \\
\text { coincidence of denial of jobs to women, \& } \\
\text { to Muslims }\end{array}$ & $\begin{array}{l}\text { Some firms recruit "excellent" women } \\
\text { employees, give good WLB benefits } \\
\text { Patriarchal managers deny promotion } \\
\text { beyond certain levels; glass ceiling remains; } \\
\text { women pushed into specialist roles but } \\
\text { denied full leadership }\end{array}$ \\
\hline $\begin{array}{c}\text { Micro Level } \\
\text { Positive Trends } \\
\text { Negative Trends }\end{array}$ & $\begin{array}{l}\text { Unique examples of positive hiring } \\
\text { in some firms/sectors } \\
\text { Some firms/sectors fail to } \\
\text { recruit/promote women for } \\
\text { idiosyncratic or cultural reasons }\end{array}$ & $\begin{array}{l}\text { Muslim women's mutual support groups } \\
\text { Some Muslim women forced to stay home } \\
\text { due to patriarchal, non-Islamic values of } \\
\text { male family members }\end{array}$ & $\begin{array}{l}\text { Some firms have good hiring profiles for } \\
\text { women. } \\
\text { Most firms operate patriarchal values, } \\
\text { male-centred non-hiring or non-promoting } \\
\text { of women }\end{array}$ \\
\hline Net Results & $\begin{array}{l}\text { At least a } 75 \% \text { of top companies } \\
\text { have no women in senior roles }\end{array}$ & $\begin{array}{l}\text { Muslim women forced to stay at home; } \\
\text { and Muslim men discriminated against } \\
\text { too, with poverty level status for many }\end{array}$ & $\begin{array}{l}\text { Many women remain as (strong) child carers } \\
\text { and home educators; some have brief work } \\
\text { experience before becoming full-time family } \\
\text { managers. Very few Muslim women senior } \\
\text { managers exist }\end{array}$ \\
\hline
\end{tabular}

Note: Format of model based on conclusions and proposals of Mahadevan et al. (2017) [43] [44], and Ali et al. (2016) [35]. "Western" indicates nations in which a majority of the population are of European ancestry.

\section{Conclusions}

In writing this essay on Muslim women's progress towards executive managerial and professional roles in both Western and Muslim majority countries, we realised that we had to consider the literature on women in management in Western society, regardless of their ethnicity or religion. This exercise has given us insights, from the work of Helgeson and Johnson (1990 \& 2010; 2018) [11] [12] into how women managers have (or deploy) special strengths in managing complex situations, by means of empathy, astuteness of perception, emotional bonding, caring for employees, holistic perception and other traits not greatly used, or used to similar effect, by their male counterparts. We are impressed by the similarities between the feminist managerial models of Helgeson \& Johnson (2010) [11] and the accounts of women in Islam, as enjoying a duality of roles as family managers and community leaders in ways which are quite different from the roles normatively (and spiritually) prescribed for men. Women in Islam have special strengths based on their family roles which enable them to be strong, caring, intuitive, empathic, perceptive managers. Moreover, in the commercial world of Islam in which service rather than profit is an over-riding goal, woman as super-managers of family and firm have an ideal role.

This is of course an ideal model, and is emerging only in some modernising Arabic cultures in which values of patriarchy are giving way to those of Islam. The renaissance of Islam in its Western mode is described eloquently by Tariq Ramadan [61]: Muslims in the West are not merely first or second-generation 
immigrants. Islam is a major force in multicultural Europe, with an equality of intellectual and moral energy that matches other groups in multicultural, plural societies (Bagley \& Al-Refai, 2017) [79]. This firm Islamic identity has an interesting interplay with modernising Arabic and Muslim societies across the world (Sultan, Weir \& Karake-Shalhoub, 2011) [69]. Women in Muslim majority cultures are gaining power through their educational advancement, which inevitably leads to pressures to achieve occupational success.

What we advocate, in conclusion, is a series of qualitative studies of companies in MMCs in which, as did Helgeson \& Johnson (1990/2010 \& 2018) [11] [12], researchers can identify successful women in management, and through their biographies and accounts of their daily decisions, show how Muslim women may absorb and balance Islamic and Western norms and values in making a success of being "super managers". In our critical realist model (Bagley, Sawyerr \& Abubaker, 2016) [45] the Muslim model of gender relations, equality, modesty and mutual respect between men and women, are a structural "givens" which forms the value base of such a research program. In this dialectical research model, our intuitive, initial hypothesis is that Muslim women become strong managers because of their family status, and in commercial and industrial settings women will carry forward their strengths as "strong family managers".

This model, we believe, is compatible with the theologically derived management and business models which Islam implies, as outlined by Murphy \& Smolarski (2018) [16] who argue that “... large firms within Muslim majority countries have the moral obligation to assist governments in addressing challenges related to sustainable socioeconomic development and in advancing human rights... we draw upon the Islamic business ethics, stakeholder theory, and corporate governance literatures, as well as the concepts of Maqasid al Shariah (the objectives of Islamic law) and fard al "ayn (obligation upon all individuals within society) ... to introduce a normative model elucidating critical Islamic precepts.” (p. 1)

\section{References}

[1] Syed, J. and Pio, E. (2016) Muslim Diaspora in the West and International Human Relations Management. International Journal of Human Resource Management, 10, 115-137.

[2] Rizzo, H., Abdel-Latif, A. and Meyer, K. (2007) The Relationship between Gender Equality and Democracy: A Comparison of Arab versus Non-Arab Muslim Societies. Sociology, 41, 1151-1170. https://doi.org/10.1177/0038038507082320

[3] Alvesson, M. and Billing, Y.D. (1997) Understanding Gender and Organizations. Sage, London.

[4] Paludi, M. (2013) Women and Management: Global Issues and Promising Solutions. Praeger, New York.

[5] ILO (2015) Women in Business and Management: Gathering Momentum. International Labor Office, Geneva.

[6] World Bank (2012) Gender Equality and Development. The World Bank, Wash- 
ington DC.

[7] Catalyst (2017) Women in Management. The Catalyst Institute, New York.

[8] Francke, A. (2014) Women in Management: The Power of Role Models. Chartered Management Institute, London.

[9] Carter, N.M. and Silva, C. (2010) Women in Management: Delusions of Progress. Harvard Business Review, 88, 19-21.

[10] Metcalfe, B.D. (2011) Women, Empowerment and Development in Arab Gulf States: A Critical Appraisal of Governance, Culture and National Human Resource Development (HRD) Frameworks. Human Resource Development International, 14, 131-148. https://doi.org/10.1080/13678868.2011.558310

[11] Helgeson, S. and Johnson, J. (1990 and 2010) The Female Vision: Women's Real Power at Work. 1st and 2nd Editions, Barrett-Koehler Publishers, San Francisco.

[12] Helgeson, S. (2018) Women Rise. https://sallyhelgeson.com/

[13] Parmar, B. (2014) The Empathy Era: Business and the New Pathway to Profit. Lady Geek Publications, London.

[14] Gordon, S. (2016) Women Hold Just a Sixth of Senior Roles at Top UK Companies. Financial Times, 16 May 2016.

[15] Bullough, A., Moore, F. and Kalafatoglu, T. (2017) Research on Women in International Business and Management: Then, Now and Next. Cross-Cultural and Strategic Management, 24, 211-230. https://doi.org/10.1108/CCSM-02-2017-0011

[16] Murphy, M. and Smolarski, J. (2018) Religion and CSR: An Islamic "Political" Model of Corporate Governance. Business \& Society.

[17] Kerfoot, D. and Knights, D. (1994) Into the Realm of the Fearful: Power, Identity and the Gender Problematic. In: Radtke, H.L. and Stam, H.J., Eds., Power/Gender. Social Relations in Theory and Practice, Sage, London, 67-88.

[18] Knights, D. (2017) Introduction to "Masculinities: A Non/Contested Terrain". Gender Work and Organisation.

[19] Bates, L. (2014) Everyday Sexism. Simon \& Schuster, London.

[20] Knights, D. (2015) Binaries Need to Shatter for Bodies to Matter: Do Disembodied Masculinities Undermine Organizational Ethics? Organization, 22, 200-216. https://doi.org/10.1177/1350508414558724

[21] Phoenix, A. and Pattynama, P. (2006) Intersectionality. European Journal of Women's Studies, 13, 187-192. https://doi.org/10.1177/1350506806065751

[22] Shen, J., Chanda, A., Netto, B. and Monga, M. (2009) Managing Diversity through Human Resource Management: An Intersectional Perspective and Conceptual Framework. The International Journal of Human Resource Management, 20, 235-251. https://doi.org/10.1080/09585190802670516

[23] Purdie-Vaughns, V. and Eibach, R. (2008) Intersectional Invisibility: The Distinctive Advantages and Disadvantages of Multiple Subordinate-Group Identities. Sex Roles, 59, 337-391. https://doi.org/10.1007/s11199-008-9424-4

[24] Ng, E.S.W. and Sears, G.J. (2010) What Women and Ethnic Minorities Want. Work Values and Labor Market Confidence: A Self-Determination Perspective. International Journal of Human Resource Management, 21, 676-698. https://doi.org/10.1080/09585191003658847

[25] Goffman, E. (1978) The Presentation of Self in Everyday Life. Penguin Books, London.

[26] Afshar, H., Ed. (2012) Women and Fluid Identities: Strategic and Practical Path- 
ways Selected by Women. Palgrave Macmillan, Basingstoke. https://doi.org/10.1057/9781137265302

[27] Veenstra, G. (2013) The Gendered Nature of Discriminatory Experiences by Race, Class, and Sexuality: A Comparison of Intersectionality Theory and the Subordinate Male Target Hypothesis. Sex Roles, 68, 646-659.

https://doi.org/10.1007/s11199-012-0243-2

[28] Grine, F. (2014) Empowering Muslim Women through Coaching and Mentoring. International Journal of Nusantara Islam, 2, 54-68. https://doi.org/10.15575/ijni.v2i1.48

[29] Mahadevan, J. and Mayer, C.-H., Eds. (2017) Muslim Minorities, Workplace Diversity and Reflexive HRM. Routledge-Gower, London.

[30] Kamenou, N. and Fearful, A. (2006) Ethnic Minority Women: A Lost Voice in HRM. Human Resource Management Journal, 16, 154-172. https://doi.org/10.1111/j.1748-8583.2006.00010.x

[31] Kumra, S. and Manfredi, S. (2012) Managing Equality and Diversity: Theory and Practice. Oxford University Press, London.

[32] Abubaker, M. and Bagley, C. (2017) Methodology of Correspondence Testing for Employment Discrimination Involving Ethnic Minority Applications: Dutch and English Case Studies of Muslim Applicants for Employment. Social Sciences, 6, 112-120. https://doi.org/10.3390/socsci6040112

[33] Bagley, C. and Abubaker, M. (2017) Muslim Woman Seeking Work: An English Case Study with a Dutch Comparison, of Discrimination and Achievement. Social Sciences, 6, 17. https://doi.org/10.3390/socsci6010017

[34] Ali, A.J. (2017) An Islamic View of Diversity: Implications for the Business World. In: Syed, J. and Klarsfield, A., Eds., Religious Diversity in the Workplace, Cambridge University Press, Cambridge, 100-125.

https://doi.org/10.1017/9781316477106.005

[35] Ali, F., Malik, A., Pereira, V. and Al Ariss, A. (2016) A Relational Understanding of Work-Life Balance of Muslim Migrant Women in the West: Future Research Agenda. International Journal of Research on Human Management, 28, 1163-1181.

[36] Syed, J. and Özbilgin, M., Eds. (2015) Managing Diversity and Inclusion: An International Perspective. Sage, London.

[37] Syed, J. (2008) A Context-Specific Perspective of Equal Employment Opportunity in Islamic Societies. Asia Pacific Journal of Management, 25, 135-151. https://doi.org/10.1007/s10490-007-9051-6

[38] Syed, J., Ali, F. and Winstanley, D. (2005) In Pursuit of Modesty: Contextual Emotional Labor and the Dilemma for Working Women in Islamic Societies. International Journal of Work, Organization and Emotion, 1, 150-167. https://doi.org/10.1504/IJWOE.2005.008819

[39] Syed, J., Klarsfeld, A., Ngunjiri, F. and Härtel, C. (Eds.) (2017) Religious Diversity in the Workplace. Cambridge University Press, Cambridge.

[40] Syed, J. and Özbilgin, M. (2009) A Relational Framework for International Transfer of Diversity Management Practices. International Journal of Human Resource Management, 20, 2435-2453. https://doi.org/10.1080/09585190903363755

[41] Rodriguez, J.K., Holvino, E., Fletcher, J.K. and Nkomo, S.M. (2016) The Theory and Praxis of Intersectionality in Work and Organisations: Where Do We Go from Here? Gender, Work \& Organization, 23, 201-222.

https://doi.org/10.1111/gwao.12131 
[42] Eden, L. and Gupta, S.F. (2017) Culture and Context Matter: Gender in International Business and Management. Cross-Cultural and Strategic Management, 24, 194-210. https://doi.org/10.1108/CCSM-02-2017-0020

[43] Mahadevan, J. (2017) Cross-Cultural Management. Sage, London.

[44] Mahadevan, J. and Kilian-Yasin, K. (2017) Dominant Discourse, Orientalism and the Need for Reflexive HRM: Skilled Muslim Migrants in the German Context. The International Journal of Human Resource Management, 28, 1140-1162. https://doi.org/10.1080/09585192.2016.1166786

[45] Bagley, C., Sawyerr, A. and Abubaker, M. (2016) Dialectic Critical Realism: Grounded Values and Reflexivity in Social Science Research. Advances in Applied Sociology, 6, 400-419. https://doi.org/10.4236/aasoci.2016.612030

[46] Tariq, M. and Syed, J. (2017) Intersectionality at Work: South Asian Muslim Women's Experiences of Employment and Leadership in the United Kingdom. Sex Roles, 77, 510-522.

[47] Mernissi, F. (1991) Women and Islam. Blackwell, Oxford.

[48] Wadud, A. (1999) Qur'an and Women: Rereading the Sacred Text from a Woman's Perspective. Oxford University Press, Oxford.

[49] Esposito, J.L. (2003) Women in Islam. In: Esposito, J.L., Ed., The Oxford Dictionary of Islam, Oxford University Press, Oxford, 339-340.

[50] Ghandanfar, M.A. (2001) Great Women of Islam. Darussalam Publications, Birmingham.

[51] Esposito, J.L. (1998) Islam: The Straight Path. Oxford University Press, Oxford.

[52] Hashmi, T. (2000) Women and Islam in Bangladesh: Beyond Subjugation and Tyranny. Palgrave Macmillan, London. https://doi.org/10.1057/9780333993873

[53] Shanaz, A., Bagley, C., Kadri, S. and Simkhada, P. (2017) Suicidal Behaviour in Bangladesh: Scoping Literature Review, and Development of a Public Health Research and Prevention Model. Open Journal of Social Science, 5, 254-282.

https://doi.org/10.4236/jss.2017.57016

[54] Bagley, C., Shahnaz, A. and Simkhada, P. (2017) High Rates of Suicide and Violence in the Lives of Girls and Young Women in Bangladesh: Issues for Feminist Intervention. Social Sciences, 6, 140-158. https://doi.org/10.3390/socsci6040140

[55] Mernissi, F. (2001) Beyond the Veil: Male-Female Dynamics in Modern Muslim Society. Indiana University Press, Indiana.

[56] Roald, A.S. (2001) Women in Islam: The Western Experience. Routledge, London.

[57] Al-Khayyat, M.H. (2003) Woman in Islam and Her Role in Human Development. World Health Organisation, Eastern Mediterranean Office, Cairo.

[58] Anwar, E. (2006) Gender and Self in Islam. Routledge, London.

[59] Lovat, T. (2012) The "Women's Movement" in Modern Islam: Reflections on the Revival of Islam's Oldest Issue. In: Lovat, T., Ed., Women in Islam: Reflections on Historical Contemporary Research, Springer, Dordrecht, 1-9. https://doi.org/10.1007/978-94-007-4219-2_1

[60] Ahmed, L. (1992) Women and Gender in Islam. Yale University Press, New Haven.

[61] Ramadan, T. (2010) What I Believe. Oxford University Press, Oxford.

[62] Ezzat, H.R. (2007) On the Future of Women in Politics in the Arab World. In: Esposito, J.L. and Donohue, J., Eds., Islam in Transition: Muslim Perspectives, Oxford University Press, Oxford, 184-196.

[63] Ezzat, H.R. (2008) Muslim Women at the Cross-Roads: Cultural and Religious 
Rules versus Religious Imperatives. In: Fadel, H., Misha'l, A. and Ebrahim, A., Eds., Women's Issues. Islamic Perspective, Federation of Islamic Medical Associations, Jordan, 93-100.

[64] Ahmad, K. (2004) Islamization and Private Enterprise: Can the Two Work Together? In: Hathaway, R. and Lee, W., Eds., Islamization and the Pakistani Economy, Woodrow Wilson International Center for Scholars, Washington DC, 37-44.

[65] Jamili, D., Sidani, Y. and Safieddine, A. (2005) Constraints Facing Working Women in Lebanon: An Insider View. Women in Management Review, 20, 581-594. https://doi.org/10.1108/09649420510635213

[66] Sidani, Y. (2005) Women, Work, and Islam in Arab Societies. Gender in Management, 20, 498-512. https://doi.org/10.1108/09649420510624738

[67] Kalafatoglu, T. and Mendosa, X. (2017) The Impact of Gender and Culture on Networking and Venture Creation: An Exploratory Study in Turkey and the MENA Region. Cross-Cultural and Strategic Marketing, 24, 332-349. https://doi.org/10.1108/CCSM-04-2016-0090

[68] Spierings, N. (2015) Women's Employment in Muslim Countries: Patterns of Diversity. Palgrave-Macmillan, Basingstoke, UK.

[69] Sultan, N., Weir, D. and Karake-Shalhoub, Z. (2011) The New Post-Oil Arab Gulf: Managing People and Wealth. Saqi Books, London.

[70] Branine, M. and Pollard, D. (2010) Human Resource Management with Islamic Management Principles: A Dialectic for a Reverse Diffusion in Management. Personnel Review, 39, 712-727. https://doi.org/10.1108/00483481011075576

[71] Hutchings, K., Metcalfe, B.D. and Cooper, B.K. (2010) Exploring Arab Middle Eastern Women's Perceptions of Barriers to, and Facilitators of, International Management Opportunities. The International Journal of Human Resource Management, 21, 61-83. https://doi.org/10.1080/09585190903466863

[72] Mellahi, K., Demirbag, M. and Riddle, L. (2011) Multinationals in the Middle East: Challenges and Opportunities. Journal of World Business, 46, 406-410. https://doi.org/10.1016/j.jwb.2010.10.001

[73] Abubaker, M. and Bagley, C. (2016) Work-Life Balance and the Needs of Female Employees in the Telecommunications Industry in a Developing Country: A Critical Realist Approach to Issues in Industrial and Organisational Psychology. Comprehensive Psychology, 5, 1-12. https://doi.org/10.1177/2165222816648075

[74] Metcalfe, B.D. (2006) Women, Management and Globalization in the Middle East. Journal of Business Ethics, 83, 85-100. https://doi.org/10.1007/s10551-007-9654-3

[75] Metcalfe, B.D. (2007) Gender and Human Resource Management in the Middle East. International Journal of Human Resource Management, 18, 54-74. https://doi.org/10.1080/09585190601068292

[76] Metcalfe, B.D., Hutchings, K. and Cooper, B. (2009) Re-Examining Women's International Management Opportunities and Experiences: A Middle Eastern Perspective. In: Ibeh, K. and Davies, S., Eds., Contemporary Challenges to International Business, Palgrave Macmillan, London, 232-250.

[77] Metcalfe, B. and Mimouni, F., Eds. (2011) Leadership Development in the Middle East. Edward Elgar Publishing, Cheltenham. https://doi.org/10.4337/9780857938114

[78] Metcalfe, B. and Rees, C.J. (2010) Gender, Globalization and Organization: Exploring Power, Relations and Intersections. Equality, Diversity and Inclusion, 29, 5-22. https://doi.org/10.1108/02610151011019183

[79] Bagley, C. and Al-Refai, N. (2017) Multicultural Integration in British and Dutch 
Societies: Education and Citizenship. Journal for Multicultural Education, 11, 82-100. https://doi.org/10.1108/JME-12-2015-0040

[80] Budhwar, P. and Mellahi, K., Eds. (2006) Managing Human Resources in the Middle-East. Routledge, London.

[81] Omair, K. (2008) Women in Management in the Arab Context. Education, Business and Society. Contemporary Middle Eastern Issues, 1, 107-123. https://doi.org/10.1108/17537980810890293

[82] Omair, K. (2010) Typology of Career Development for Arab Women Managers in the United Arab Emirates. Career Development International, 15, 121-143. https://doi.org/10.1108/13620431011040932

[83] Panjalingam, P. (2012) Muslim Women Today: Challenges in Achieving Their Potential in Resources Management. In: Ibrahim, H. and Islam, R., Eds., Management of Resources in Muslim Communities. Challenges and Prospects, HUM Press, University of Malaysia, Malaysia, 97-112.

[84] Saeed, A., Yousaf, A. and Alharbi, J. (2017) Family and State Ownership, Internalization and Corporate Board-Gender Diversity: Evidence from China and India. Cross-Cultural Strategic Management, 24, 251-270.

https://doi.org/10.1108/CCSM-11-2015-0159

[85] Kemp, L.J., Madsen, S. and Davis, J. (2015) Women in Business Leadership: A Comparative Study of Countries in the Arab Gulf States. International Journal of Cross Cultural Management, 15, 215-233. https://doi.org/10.1177/1470595815594819

[86] Abuznaid, S. (2006) Islam and Management: What Can Be Learned? Thunderbird International Business Review, 48, 125-139. https://doi.org/10.1002/tie.20089

[87] Coleman, I. (2004) Gender Disparities, Economic Growth and Islamization in Pakistan. In: Hathway, R. and Lee, W., Eds., Islamization and the Pakistani Economy, Woodrow Wilson International Center for Scholars, Washington DC, 79-90.

[88] Morin, A., Fitima, H. and Qadir, T. (2018) Pakistan's Slow Progress towards Gender Parity. The Lancet Global Health, 6, e144. https://doi.org/10.1016/S2214-109X(17)30498-9

[89] Abbas, J.A. (2005) Islamic Perspectives of Management and Organisation. Edward Elgar, Cheltenham, UK.

[90] Abubaker, M. and Bagley, C. (2016) Work-Life Benefits: Managers' Views on Implementation in Jordanian Telecommunication Companies. Eurasian Journal of Business and Management, 4, 13-28. https://doi.org/10.15604/ejbm.2016.04.03.002

[91] Nydell, M.K. (2012) Understanding Arabs. 5th Edition, Intercultural Press, Boston MA. 